\title{
Critical review of asphaltene properties and factors impacting its stability in crude oil
}

\author{
Sherif Fakher ${ }^{1} \cdot$ Mohamed Ahdaya $^{1} \cdot$ Mukhtar Elturki $^{1} \cdot$ Abdulmohsin Imqam $^{1}[$
}

Received: 13 September 2019 / Accepted: 24 November 2019 / Published online: 5 December 2019

(c) The Author(s) 2019

\begin{abstract}
Asphaltene is a component of crude oil that has been reported to cause severe problems during production and transportation of the oil from the reservoir. It is a solid component of the oil that has different structures and molecular makeup which makes it one of the most complex components of the oil. This research provides a detailed review of asphaltene properties, characteristics, and previous studies to construct a guideline to asphaltene and its impact on oil recovery. The research begins with an explanation of the main components of crude oil and their relation to asphaltene. The method by which asphaltene is quantified in the crude oil is then explained. Due to its different structures, asphaltene has been modeled using different models all of which are then discussed. All chemical analysis methods that have been used to characterize and study asphaltene are then mentioned and the most commonly used method is shown. Asphaltene will pass through several phases in the reservoir beginning from its stability phase up to its deposition in the pores, wellbore, and facilities. All these phases are explained, and the reason they may occur is mentioned. Following this, the methods by which asphaltene can damage oil recovery are presented. Asphaltene rheology and flow mechanism in the reservoir are then explained in detail including asphaltene onset pressure determination and significance and the use of micro- and nanofluidics to model asphaltene. Finally, the mathematical models, previous laboratory, and oilfield studies conducted to evaluate asphaltene are discussed. This research will help increase the understanding of asphaltene and provide a guideline to properly study and model asphaltene in future studies.
\end{abstract}

Keywords Asphaltene $\cdot$ Critical review $\cdot$ Oil recovery $\cdot$ Pore plugging $\cdot$ Wettability change $\cdot$ Flow behavior

\section{List of symbols}

$\delta \quad$ Asphaltene and crude oil solubility parameter

$\Delta H^{\mathrm{L}} \quad$ Enthalpy change

$R \quad$ Universal gas constant

$T$ Temperature

$v^{\mathrm{L}} \quad$ Volume

$\emptyset \quad$ Volume fraction

A Fraction of asphaltene

$f \quad$ Fraction

$\mu_{\text {cAi }} \quad$ Viscosity

$V_{\mathrm{fAi}} \quad$ Initial volume fraction of asphaltene

$N_{\text {sAi }} \quad$ Segment number

$\emptyset_{\mathrm{r}} \quad$ Volume fraction of resins in the mixture

$v_{\mathrm{r}} \quad$ Molar volume of resins

$v_{\mathrm{m}} \quad$ Molar volume of mixture

$\delta_{\mathrm{m}} \quad$ Solubility parameter of mixture

Abdulmohsin Imqam

ahikx7@mst.edu

1 Missouri University of Science and Technology, Rolla, USA $\delta_{\mathrm{r}} \quad$ Solubility parameter of resins

$M_{\mathrm{Ai}} \quad$ Asphaltene molecular weight

$V^{\mathrm{s}} \quad$ Volume of solid phase

$F \quad$ Distribution function

C Correction term for asphaltene

$S \quad$ Ratio of volume of injected solvent to the weight

of crude oil

W Weight percent

Z Constant

GOR Gas-oil ratio

$x \quad$ Maltene solvency power

\section{Introduction}

Asphaltene was first defined by Boussingault (1837) as the "distillation residue of bitumen insoluble in alcohol and soluble in turpentine." This definition was later modified, however, due to an error in the initial part of the definition, which limited asphaltene presence to bitumen; this was later found to be incorrect (Golkari and Riazi 2017; Salleh et al. 2019). 
Today, asphaltene is defined as "the heaviest component of petroleum fluids that is insoluble in light $n$-alkanes such as $n$-pentane or $n$-heptane, but soluble in aromatics such as toluene" (Goual 2012). Asphaltene is therefore a solid component of crude oil with an extremely high molecular weight (Mozaffari et al. 2015, 2017a, b, 2018; Struchkov et al. 2019; Kor et al. 2017; Nwadinigwe et al. 2015). This is the main reason causing it to be extremely problematic, since it can form dense flocculations and deposits in reservoir, wellbores, and transportation pipelines and thus can cause severe operational and production problems.

Much research has been conducted to study the precipitation and deposition of high molecular weight components, mainly asphaltene, in the pore spaces of conventional oil reservoirs. Zendehboudi et al. (2014) defined precipitation as the formation of the solid phase from the liquid phase and defined deposition as the adherence or adsorption of the solid phase to the reservoir rock, which usually occurs after precipitation. Asphaltene also forms dense clusters referred to as flocculations (Leandra et al. 2018; Liu et al. 2017; Fakher et al. 2019). The flocculations have a high density and thus tend to deposit and plug the pore throats in the reservoir (Monger and $\mathrm{Fu}$ 1987; Kim et al. 1990; Rassamdana et al. 1996; Khamehchi et al. 2018; Ihtsham and Ghosh 2015). The most severe of all the high molecular weight components is asphaltene (Thawer et al. 1990). Therefore, many methods have been proposed to detect asphaltene deposition in conventional oil reservoirs, such as the De Boer plot (De Boer et al. 1995), the asphalteneto-resin ratio approach (Jamaluddin et al. 2000), the colloidal instability index (Yen et al. 2001), filtration, the acoustic resonance technique, the light scattering technique (Speight et al. 1985; Speight 1999; Jamaluddin et al. 2000; Akbarzadeh et al. 2007), optical spectroscopy (Kharrat et al. 2013), nuclear magnetic resonance (Wang et al. 2016), and gas chromatography coupled with mass spectrometry (Fakher et al. 2018; Elkahky et al. 2019; Iraji and Ayatollahi 2019; Ahmadi 2011; Gholami et al. 2016; Kargarpour and Dandekar 2016).

Extensive experiments have been conducted to model asphaltene deposition during $\mathrm{CO}_{2}$ injection in conventional oil reservoirs. Soroush et al. (2014) showed that below $\mathrm{CO}_{2}$ minimum miscibility pressure (MMP), an increase in pressure will result in an increase in asphaltene deposition in sandstone, whereas, above $\mathrm{CO}_{2} \mathrm{MMP}$, an increase in pressure results in a decrease in asphaltene deposition. Thawer et al. (1990) ran laboratory tests to determine the minimum solubility pressure for asphaltene in the Ula reservoir fluids. They also tested several chemical formulations that could dissolve asphaltene and found that the chemicals that could dissolve asphaltene most effectively were pure aromatics such as toluene and xylene. However, pure xylene and toluene were considered dangerous to use due to their low flash point, and hence, the chemical formulations were considered safer and more stable. Thomas et al. (1995) also sought to find a method to dissolve asphaltene that was deposited in the reservoirs and pipelines. By testing several chemicals, they developed three chemical formulations that could effectively dissolve the asphaltene that was present in the oil. Shen and Sheng (2018) studied asphaltene deposition in the Eagle Ford shale reservoir using cyclic gas injection. They used filter membranes of $30 \mathrm{~nm}$, $100 \mathrm{~nm}$, and $200 \mathrm{~nm}$ to study asphaltene precipitation and deposition. The experiments they conducted with the filter membranes were conducted at $50 \mathrm{psi}$ and room temperature. Fakher and Imqam (2018a, b) studied asphaltene instability in crude oil during $\mathrm{CO}_{2}$ injection in nanofilter membranes at different experimental conditions.

Based on the aforementioned, it is clear that asphaltene is an extremely complex component of crude oil and the methods by which it is studied are abundant and differ significantly. Due to the numerous amount of methods by which asphaltene has been studied, it becomes tedious to comprehensively understand asphaltene characteristics, factors impacting its stability, and methods by which it can be accurately studied and quantified. This research provides a comprehensive understanding of asphaltene properties, characteristics, flow mechanisms and rheology, modeling and analysis methods, and its impact on oil recovery based on previous field and laboratory studies. All previous reviews on asphaltene are extremely limited in their contents and cover only one aspect of asphaltene which makes it very difficult to fully understand asphaltene properties and behavior. This research provides a comprehensive guideline to asphaltene that can be used to fully understand asphaltene properties and how to model asphaltene both experimentally and mathematically.

\section{Main components of crude oil}

Crude oil components can be divided into multiple compounds and subdivisions based on the composition of the crude oil. Normally, crude oil will contain a percentage of dissolved gasses, liquids, and solids. The liquids can be further divided into saturates, aromatics, and resins. Different types of solids may also exist in the crude oil; however, the most prominent is solid asphaltene. These components are usually grouped together as saturate-aromatic-resin-asphaltene, more commonly referred to as SARA analysis. The SARA analysis is performed using chromatography to determine the presence and concentration of the aforementioned components. The exact description of each of these components and their relation to the asphaltene is explained.

\section{Saturates}

Saturates are the compounds in the hydrocarbon that are saturated, and thus do not contain any double bonds. The carbon atoms are bonded to the maximum allowable hydrogen, 
<smiles>C</smiles><smiles>CC</smiles><smiles>CCC</smiles>

Fig. 1 Molecular structure of methane, ethane, and propane (Garner and Ham 1939)<smiles>Cc1ccccc1</smiles>

Fig. 2 Molecular structure of toluene, xylene, and phenolic acid

and thus, no carbon-carbon double bonds are present. Saturated hydrocarbons are generally referred to as alkanes. The simplest alkane compound is methane, followed by ethane and propane (Goel et al. 2017). The structure of all three compounds is shown in Fig. 1. As can be seen, no double bonds are present in the compounds. Saturates are one of the main liquid, or gas in regard to methane, components of the hydrocarbon; asphaltene is in solution within these compounds until it becomes unstable and asphaltene begins to precipitate from the solution. Saturates play no significant role in asphaltene stability; however, they are a major component of crude oil.

\section{Aromatics}

Aromatics are the second main component of hydrocarbons. These compounds are slightly more complex in structure than saturates. They are generally nonpolar and are characterized by an unsaturated hydrocarbon ring with multiple carbon-carbon double bonds within the ring configuration (Keshmirizadeh et al. 2013; Alshaikh et al. 2019; Punase et al. 2016; Liao et al. 2019; Alshaikh et al. 2018; Prakoso et al. 2017). Figure 2 shows the structure of three common aromatics, including toluene, xylene, and phenolic acid. All three compounds have a cyclic hydrocarbon ring attached to a functional group. Aromatics are generally nonpolar in nature and thus are not very stable with asphaltene since asphaltene is generally a highly polar compound.

\section{Resins}

Resins are considered much more complex in structure compared to saturates and aromatics. They have a higher molecular weight compared to the previous two components as well. Resins play a significant role in the stabilization of the asphaltene in the crude oil (Leon et al. 2002). The crude
Fig. 3 Molecular structure of simple resin molecule (AbdelRaouf 2012)<smiles></smiles>

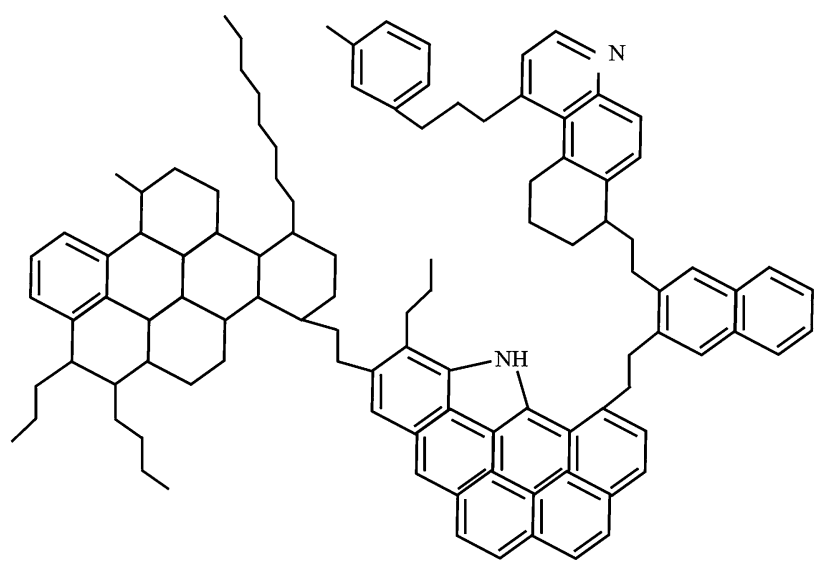

Fig. 4 Molecular structure of an asphaltene (Groenzin and Mullins 2000)

oil in general is nonpolar, which means it is insoluble in water (Lammoglia and Filho 2011). Asphaltene is usually highly polar in nature and thus cannot be homogenized or solubilized in the crude oil on its own, since it is against its nature. Resins are characterized by having both a polar side and a nonpolar side and thus function as a bridging material that connects the nonpolar hydrocarbon compounds to the highly polar asphaltene (Miadonye and Evans 2010). Figure 3 shows a typical structure of a resin molecule.

\section{Asphaltene}

Asphaltene is considered one of the most complex components of crude oils. It is one of very few components that are solid, as shown in Fig. 4. Asphaltene complexity comes mainly in the way its structure is defined. All of the three previously explained components have a general structure by which they can be classified. Unfortunately, asphaltene has many different structures, which makes generalizing it into a specific family very difficult (Pazuki 2007). Asphaltene is generally classified as a solubility class, since it is characterized as being insoluble in $n$-alkanes. There are several characteristics that can be used to identify asphaltene, including (Seifried et al. 2013):

- Solid: Asphaltene is a solid phase that is homogenized in the crude oil at reservoir conditions. 
- $n$-Alkane insoluble: Asphaltene is classified as a solubility class since it has several structures, and thus, it is extremely difficult to provide a generalized structure for it. It is therefore defined as the highest molecular weight component in the crude oil that is insoluble in light $n$-alkanes such as $n$-pentane or $n$-heptane and soluble in aromatics such as toluene or xylene.

- Highly polar: Asphaltene is one of very few components of crude oil that is highly polar, in contrast to crude oil as a whole, which is considered nonpolar.

- Heteroatoms: Asphaltene is associated with heteroatoms, mainly manifested in nitrogen, oxygen, and sulfur.

It is important to be able to differentiate between the different components of the crude oil and isolate each component from the other to both quantify the components and study each one separately. Based on this, the most common method used to differentiate between saturates, aromatics, resins, and asphaltene, which is referred to as the SARA analysis, will be explained in detail.

\section{SARA analysis}

The analysis of the four components, including saturates, aromatics, resins, and asphaltene, is referred to as the SARA analysis. The SARA analysis is conducted based on the standard test method for separation of asphalt into four fractions, which was created by the American Society for Testing and Materials (ASTM) (D-4124-97-ASTM; Fan 2003; Fan et al. 2002; Jha et al. 2014; Theyab et al. 2017). The main aim of the SARA analysis is to differentiate between and quantify the four main components of crude oil (Bissada et al. 2016). Figure 5 provides a flowchart of the SARA analysis procedure to differentiate between the different components of crude oil. If a sample of crude oil is added to liquid propane, the aromatics and saturates will be solubilized, whereas the resins and asphaltene will precipitate. This will help isolate the resins and the asphaltene. Several methods can be applied to differentiate between the aromatics and saturates, including gas chromatography. The resin and asphaltene precipitate can then be taken and dissolved in a light $n$-alkane, most notably $n$-pentane and $n$-heptane. The resin will be soluble in the $n$-alkane, whereas the asphaltene will not and will precipitate. Using this procedure, the asphaltene can be distinguished from the resin. Consequently, all four components of the SARA analysis can be accurately differentiated.

By isolating the asphaltene from the other components, a detailed study of asphaltene properties can be conducted. Initially, it is important to understand how the asphaltene structure can be modeled, especially due to the complexity of asphaltene composition and its nature of being a solid

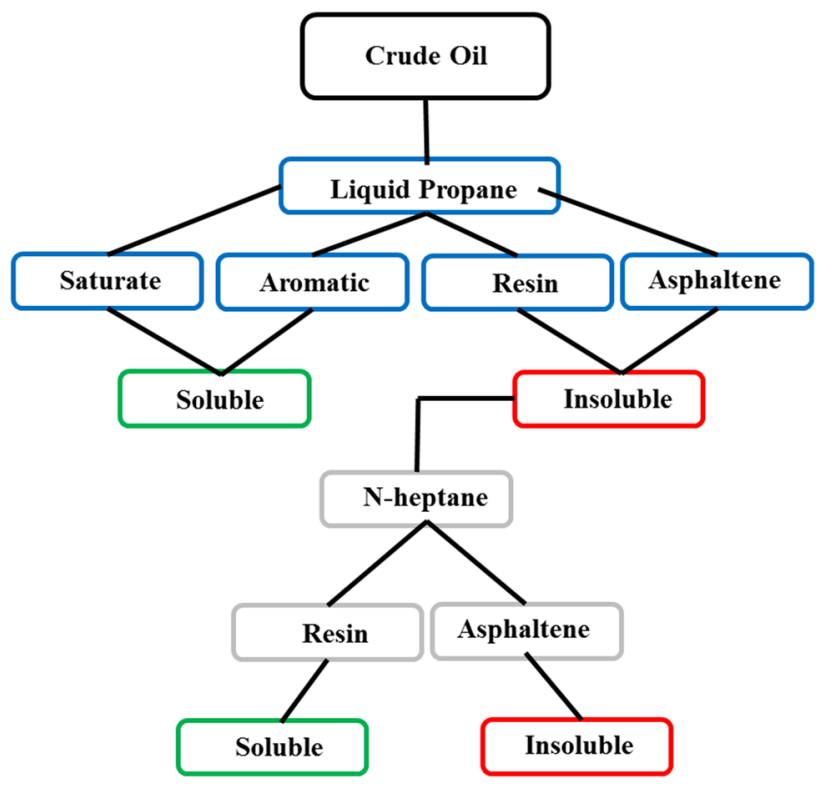

Fig. 5 SARA analysis flowchart

component in the crude oil. The different models that have arisen to attempt to describe the asphaltene structure will be explained, including the most recent and widely used model, referred to as the Yen-Mullins model.

\section{Models of asphaltene structure}

Asphaltene is extremely complex. Also, it is usually classified as a solubility class rather than a specific structure due to the several varieties of structures available for asphaltene. Several models have been developed in an attempt to provide a standard method that would be able to encompass all the different asphaltene chemical structures and model those structures.

\section{Archipelago model}

The archipelago asphaltene model, in accordance with its name, models the asphaltene structure as several aromatic rings connected together though aliphatic chains. An example of an asphaltene molecule that resembles the archipelago model is shown in Fig. 6. Several aromatic rings appear as separate groups connected together using several aliphatic chains. However, there is an uncertainty in the model regarding the number of aromatic rings present in the asphaltene molecule. The side chains are believed to have an average length of 5-7 carbons. 


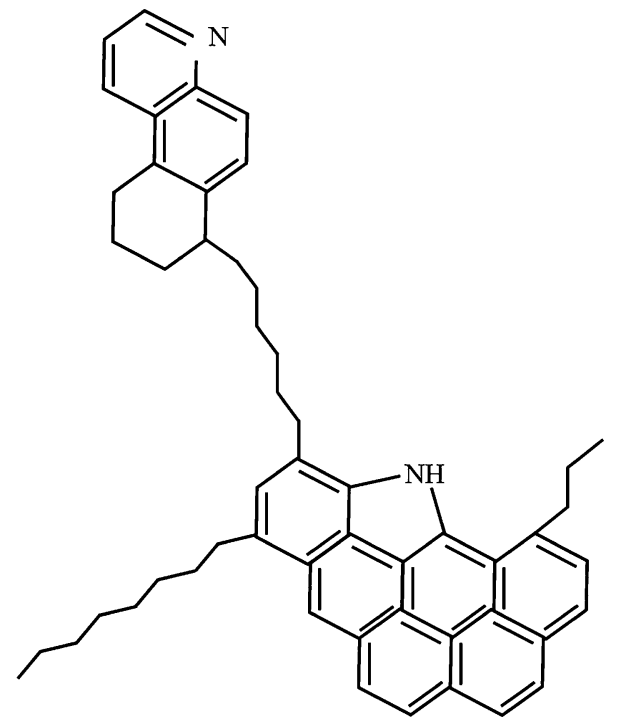

Fig. 6 Archipelago asphaltene structure (Alvarez-Ramirez and RuizMorales 2003)

\section{Continental model}

The continental model assumed the structure of asphaltene as a large group of aromatic rings in the middle of the asphaltene molecule that are connected to several aliphatic branches. This model is usually associated with lower molecular weight asphaltene and is hence referred to as the condensed aromatic model. Figure 7 shows an illustration of an asphaltene model that follows the continental model asphaltene structure.

\section{Anionic continental model}

The anionic continental model is extremely similar in structure compared to the continental model, as shown in

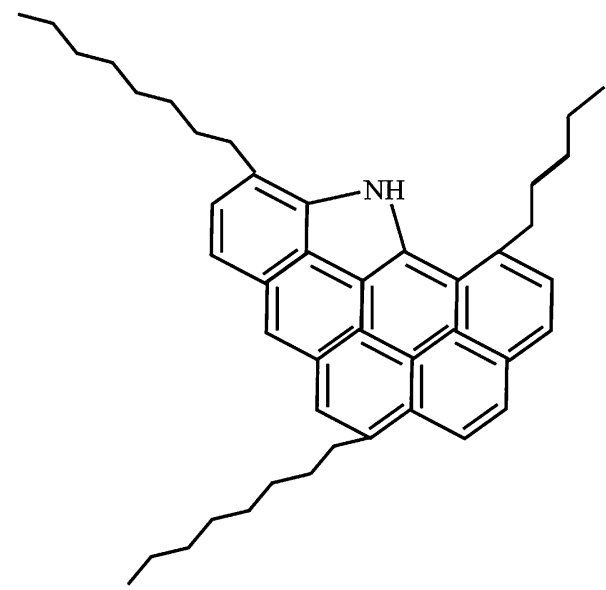

Fig. 7 Continental asphaltene structure (Kuznicki et al. 2008)
Fig. 8. The major difference lies in a negatively charged group that is attached to one of the aliphatic chains attached to the main structure. This gives the asphaltene structure a negative charge, which adds to the change in potential of the asphaltene and in turn will impact asphaltene stability significantly; this is referred to as the electrokinetic effect and will be explained in detail later on.

\section{Yen-Mullins model}

The Yen-Mullins model is the most widely accepted asphaltene model nowadays, as shown in Fig. 9 (Mullins 2011). This model describes the asphaltene structure based on size and behavior as a function of the crude oil that contains the asphaltene. In light oils, with high API gravity, the asphaltene will be present as small polyaromatic hydrocarbon molecules with an average diameter of $1.5 \mathrm{~nm}$ (Forte and Taylor 2014; Mishra et al. 2012; Seifert et al. 2012; Mullins et al. 2013). In this case, the asphaltene concentration will be relatively low, and thus, the asphaltene size will not grow. In black oils, with slightly less API gravity, the asphaltene concentration will be higher, and thus, the asphaltene will be present in the form of nanoaggregates with an average diameter of $2 \mathrm{~nm}$, which is slightly larger than the asphaltene present in light oil. In heavy oils with extremely low API gravity, the asphaltene concentration will be relatively high and will thus begin to form clusters. These clusters will grow in size and will reach an average diameter of $5 \mathrm{~nm}$. The clusters form from the combination of several nanoaggregates. Based on this model, as the asphaltene concentration in the oil increases, the oil will become heavier due to the high molecular weight of asphaltene and its API will decrease, which shows that asphaltene has an overall negative impact on the crude oil.

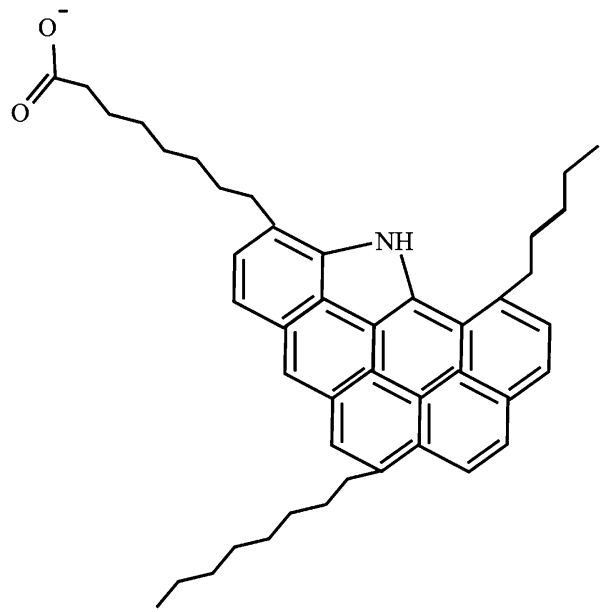

Fig. 8 Anionic continental asphaltene structure (Kuznicki et al. 2008)

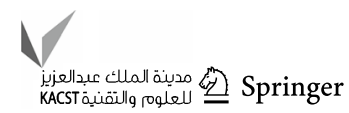




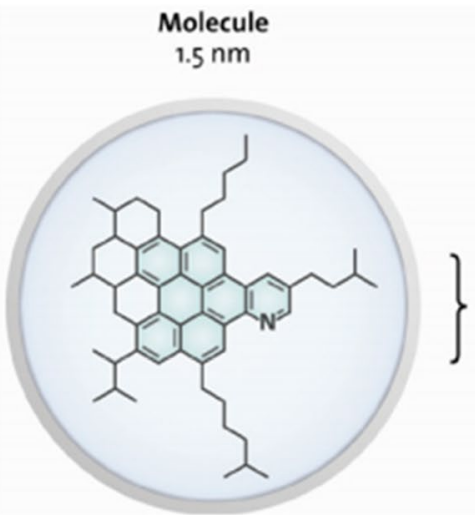

Light Oil: Asphaltene concentration is low. Isolated Molecules

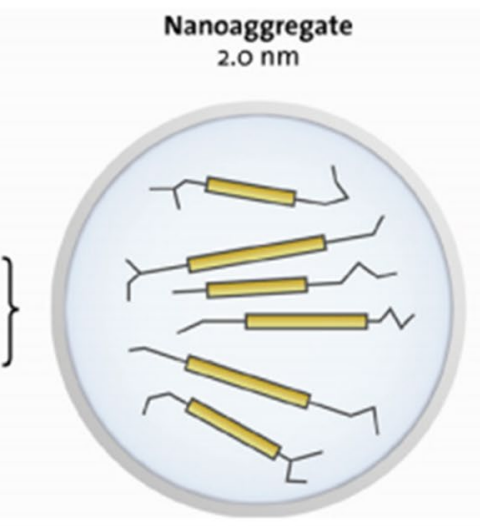

Black Oil: Asphaltene concentration is moderate. Nanoaggregates

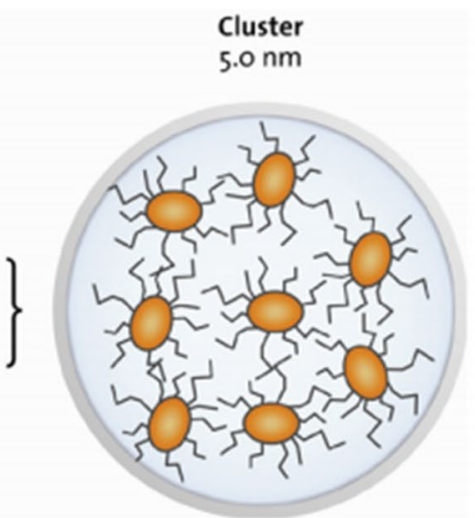

Heavy Oil: Asphaltene concentration is high. Aggregated Clusters

Fig. 9 Yen-Mullins asphaltene model (Mullins 2011)

The Yen-Mullins model provides a means of understanding the size of the asphaltene molecule and the likelihood of its presence in the crude oil. It is also important to understand how to study the chemical aspect of asphaltene and analyze the stability of asphaltene in crude oil. The different methods that have been used over the years to chemically analyze asphaltene will be presented in this research.

\section{Asphaltene chemical analysis}

Since asphaltene is extremely complex in structure and varies in composition and size, several methods are used to detect and study asphaltene structure and composition in crude oil. These methods are applied to determine several aspects of crude oil and vary in terms of accuracy and how they detect asphaltene. Some of these methods can even perform the SARA analysis by determining the different fractions of the crude oil and their compositions. Table 1 summarizes most of the methods used to study asphaltene based on different studies that have been conducted over the years. These methods include methods that are purely chemical and focus on the asphaltene structure and composition, as well as methods that are more concerned with the asphaltene composition in the crude oil, and its stability under different conditions. Also, some of the methods utilized visual setups, whereas others focused on a fractionation approach where the crude oil composition is made based on different factions within the oil, such as chromatography methods. The most common chemical methods include chromatography, where the components of the crude oil are separated based on their composition, and SARA analysis, which is mainly used to divide the four main fractions of the crude oil. The most novel methods used include the confocal laser scanning microscope and the optical spectroscopy method.

Asphaltene will behave in different ways based on the conditions available in the reservoir. Understanding the asphaltene behavior in the reservoir is important for oil recovery and asphaltene mitigation considerations. This will be explained in detail in this research.

\section{Asphaltene precipitation and deposition cycle}

The asphaltene will pass by several phases in the crude oil based on its stability and how well it remains in solution under the thermodynamic and operational conditions at which the oil is being produced (Nghiem and Coombe 1997). The different phases that the asphaltene can exhibit are shown in Fig. 10. Each of these phases will be explained in detail.

\section{Asphaltene stable}

Initially, at reservoir conditions, the asphaltene is soluble in the oil and is stable at the reservoir thermodynamic conditions. The asphaltene will remain stable in the oil until any disturbance to its equilibrium occurs. Following this disturbance, the asphaltene will begin to form solid particles inside the crude oil solution.

\section{Asphaltene precipitation}

At equilibrium conditions, the asphaltene will remain stable in the crude oil. However, once any disturbance, such as 
Table 1 Summary of chemical analysis methods of asphaltene over the years

\begin{tabular}{|c|c|}
\hline References & Analysis technique \\
\hline Jewell et al. (1972) & Anion-cation exchange chromatography \\
\hline Lichaa and Herrera (1975) & Asphaltene precipitation tests \\
\hline Hernandez et al. (1983) & SARA analysis \\
\hline Pearson and Gharfeh (1986) & Liquid chromatography with flame ionization detector \\
\hline Karlsen and Larter (1991) & Thin-layer chromatography with flame ionization detector \\
\hline Martinez et al. (1997) & Thermal cracking \\
\hline Kok et al. (1998) & Oxidation reaction and SARA analysis \\
\hline Groenzin and Mullins (2000) & Fluorescence depolarization \\
\hline Yarranton et al. (2000) & Vapor pressure osmometry \\
\hline Fan et al. (2002) & Clay-gel adsorption chromatography, thin-layer chromatography, and high-pressure liquid chromatography \\
\hline Islas-Flores et al. (2005) & Open-column chromatography and high-pressure liquid chromatography SARA analysis \\
\hline Hannisdal et al. (2006) & Infrared analysis \\
\hline Goual and Abudu (2009) & Adsorption using microbalance \\
\hline Miadonye and Evans (2010) & Calorimetry and filtration \\
\hline Bahzad et al. (2010) & Hydrodemetallization \\
\hline Angle and Hua (2012) & Dynamic light scattering microscopy \\
\hline Cho et al. (2012) & Fourier transform ion cyclotron resonance mass spectrometry with atmospheric pressure photoionization \\
\hline Keshmirizadeh et al. (2013) & Open-column, thin-layer, and gas chromatography coupled with flame ionization detector \\
\hline Kharrat et al. (2013) & Optical spectroscopy method \\
\hline Seifried et al. (2013) & Confocal laser scanning microscope \\
\hline Cendejasa et al. (2013) & Nuclear magnetic resonance \\
\hline Fakher et al. (2018) & SARA analysis using chemical methods based on heptane separation \\
\hline Fakher and Imqam (2018a, b) & Filtration based on heptane \\
\hline Fakher and Imqam (2018a, b) & SARA analysis and gas chromatography \\
\hline
\end{tabular}

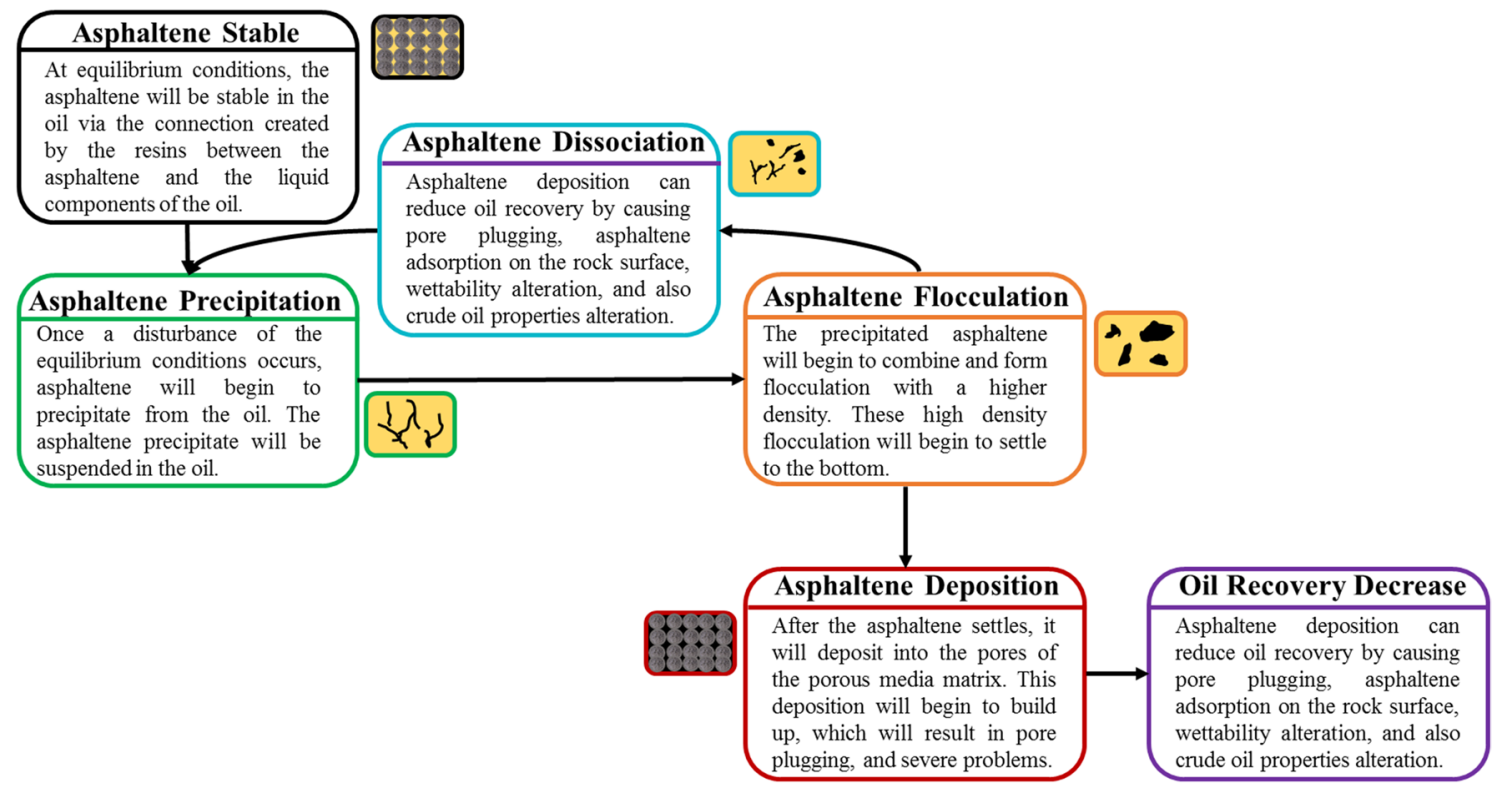

Fig. 10 Asphaltene life cycle 
production or solvent injection occurs to the oil, the asphaltene will begin to precipitate from the oil solution. Precipitation involves the asphaltene solid coming out of solution and forming visible asphaltene particles that are suspended in the oil. Since the asphaltene is still suspended in the oil, it still does not pose a large threat. The asphaltene will be mobile with the oil, as long as the precipitation does not continue to increase further.

Asphaltene stability in the crude oil can be impacted by many factors (Rogel et al. 1999). These factors can be grouped into operational factors, which are factors that are applied during production from the reservoir, and reservoir factors, which are factors that are originally native to the reservoir but are affected as production or fluid injection commences. The chart presented in Fig. 11 shows the main factors that fall under operational and reservoir factors. The reservoir conditions usually involve the reservoir thermodynamics, including pressure and temperature, and the oil properties, including solution gas, oil viscosity, and the oil classification based on its API gravity. The reservoir pressure and temperature usually do not change and are thus uncontrollable. Regarding the oil properties, these will change depending on the production mechanism, injected fluids inside the reservoir, and pressure changes as the hydrocarbon is mobilized. A solvent is any material that can be solubilized in the crude oil at different conditions based on the solvent and the reservoir properties. Several solvents can be injected into the reservoir, including steam, surfactant, $\mathrm{CO}_{2}$, nitrogen, methane, and many other solvents that are used to alter the properties of the crude oil. As the solvent begins to interact with the oil, the asphaltene might no longer be stable in the crude oil due to a shift in the equilibrium conditions at which it was initially solubilized in the oil. From its structure, the electrokinetic effect refers to the movements of a substance due to a change in charges. Asphaltene usually carries a charge, and thus, during production operations, a

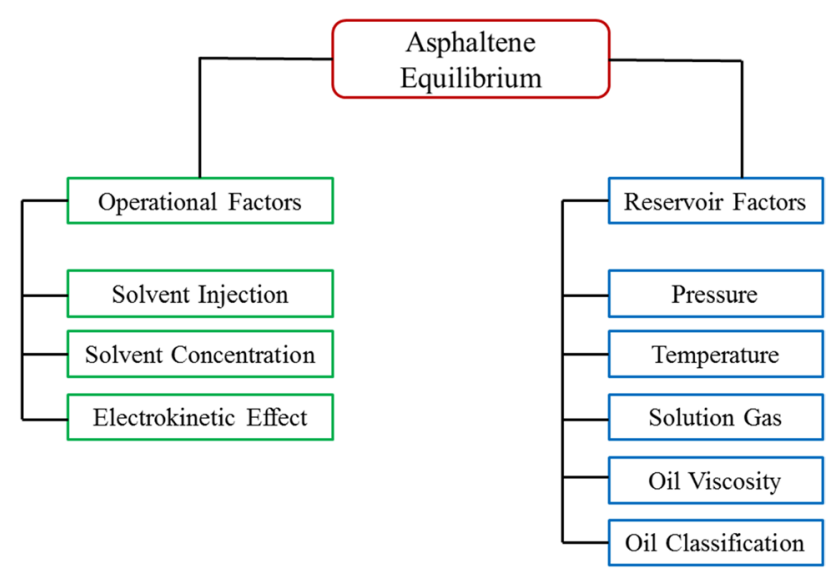

Fig. 11 Factors affecting asphaltene equilibrium in crude oil drawdown is induced due to the difference in reservoir and wellbore pressure. This drawdown and the asphaltene charge are two of the main reasons behind the electrokinetic effect, which will result in asphaltene instability in the crude oil and eventually asphaltene precipitation.

\section{Asphaltene flocculation}

If asphaltene precipitation increases, the asphaltene particles will begin to combine and form larger asphaltene flocculations with a higher density than the previously precipitated particles. These dense flocculations can pose a serious threat since the particles have a large density and thus will begin to deposit in the reservoir pores, wellbores, or pipelines.

\section{Asphaltene dissociation}

If the flocculated asphaltene particles are noticed early, they can be remediated relatively easily. If a proper remedial method is applied, the flocculations can be broken down and dissociated back into the smaller precipitated particles. If this occurs, the precipitated particles can then be homogenized in the crude oil again, usually using a stabilizing chemical reagent.

\section{Asphaltene deposition}

If the asphaltene flocculations are not immediately noticed and are left in the oil, they will begin to deposit. If a large volume of asphaltene is deposited, it will cause severe problems, such as pore plugging in the reservoir, wellbore plugging due to asphaltene buildup, or buildup in the pipeline, which will incontrovertibly result in catastrophic problems if not detected early.

\section{Asphaltene impact on oil recovery}

Once asphaltene deposition occurs, it can result in several problems in the reservoir. These problems can include pore plugging, adsorption of the asphaltene to the rock grains, and wettability alternation of the rock from its original wettability to oil wet (Soroush et al. 2014). All of these occurrences will have a strong impact on oil recovery and are considered relatively difficult to mitigate, as shown in Fig. 12.

\section{Pore plugging}

If the asphaltene begins to deposit in the reservoir pores, this deposition will begin to buildup, and eventually it will fill up all the available voids in between the pores. This will result in the pores being plugged. This pore plugging will

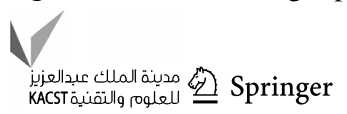




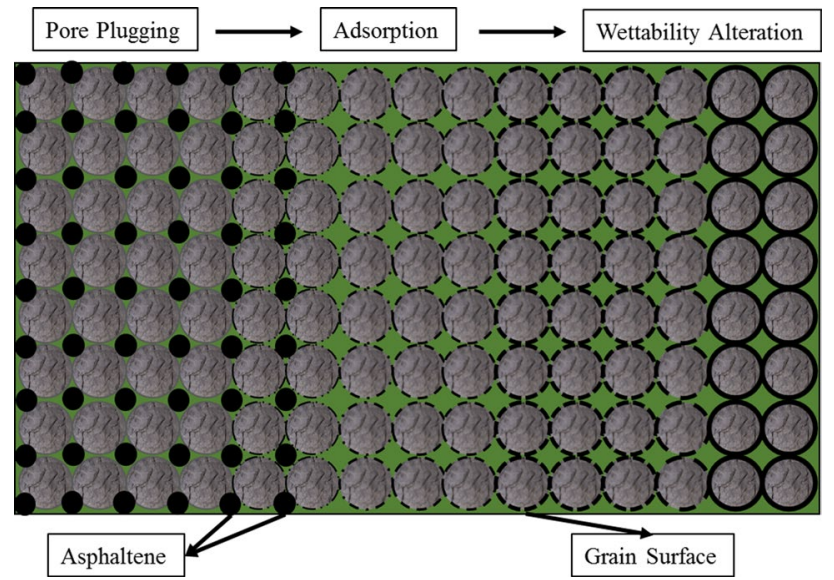

Fig. 12 Asphaltene impacts on oil recovery

deter or completely cease the flow of the oil and will thus significantly affect the oil recovery in a negative manner.

\section{Asphaltene adsorption and wettability alteration}

If the asphaltene deposition increases to a great length, the asphaltene will begin to adsorb onto the grain surface. This adsorption will result in the grains being surrounded by the asphaltene, which is a component of crude oil, and thus will result in the wettability of the oil becoming strongly oil wet. This will decrease the relative permeability of the oil and decrease oil recovery.

\section{Crude oil properties alteration}

The crude oil may undergo alterations due to asphaltene liberation from the oil, which will impact the overall oil properties. If this occurs, the oil will begin to exhibit different characteristics, such as a different flow mechanism or a different relative permeability, which in turn will make it much more difficult to predict how the oil will flow.

Based on the aforementioned problems, asphaltene can be extremely damaging for the reservoir. It is therefore extremely important to understand the rheological properties of asphaltene and how it flows in the reservoir with the crude oil.

\section{Asphaltene rheology and flow behavior}

As explained previously, asphaltene is a solid component and thus its flow mechanism and rheology are usually modeled as function of the fluid bearing the asphaltene. This section briefly discusses the rheology of asphaltene through an explanation of the asphaltene onset pressure and the solvent-to-bitumen ratio. Following this, the asphaltene flow mechanism will be discussed through the previous experiments conducted on asphaltene flow in micro- and nanofluidics.

\section{Asphaltene onset pressure}

Asphaltene onset pressure is the pressure at which asphaltene will begin to separate from the crude oil, or come out of solution (Soleymanzadeh et al. 2018). It is a strong function of many parameters including reservoir temperature, crude oil properties, and asphaltene concentration. There are multiple methods available to measure asphaltene onset pressure; the most prominent methods are explained.

- Gravimetric method: This method involves placing a live crude oil sample in a high-pressure PVT cell. The pressure is reduced in stages and oil samples are collected at each stage and analyzed for asphaltene content. Once asphaltene begins to appear, the asphaltene onset pressure is determined at isothermal conditions (Burke et al. 1990; Zendehboudi et al. 2013).

- Optical microscopy: This method utilizes a high-resolution microscope to observe samples of titrated crude oil for asphaltene precipitation (Wang and Buckley 2001).

- Density measurement: When asphaltene precipitates from the crude oil, the oil density will change. This density change can be used as an indication of the asphaltene onset pressure (Ekulu et al. 2004).

- Light scattering method: This relates light absorbance of different phases to the asphaltene onset pressure. The solid asphaltene will absorb light in a different manner than the liquid crude oil. When there is a disturbance in the light absorbance spectrum, asphaltene precipitation can be observed (Hammami et al. 2000).

- Refractive index: It is a function that depends on the oil density, along with polarizability and oil molecular weight (Castillo et al. 2009).

The asphaltene onset pressure is one of the main parameters that control the asphaltene phase envelope. An example of an asphaltene phase envelope is shown in Fig. 13 (Akbarzadeh et al. 2007). This can be used to determine the phase of asphaltene and the pressure and temperature conditions at which asphaltene will begin to precipitate. Different phase envelopes are developed for different crude oils.

\section{Solvent-to-bitumen ratio}

Solvent injection in crude oil is usually applied to increase the mobility of the oil, especially heavy crudes, and reduce its viscosity. The interaction of the solvent with the oil can impact asphaltene stability. The solvent-to-bitumen ratio is an index that can be used to determine asphaltene stability. 


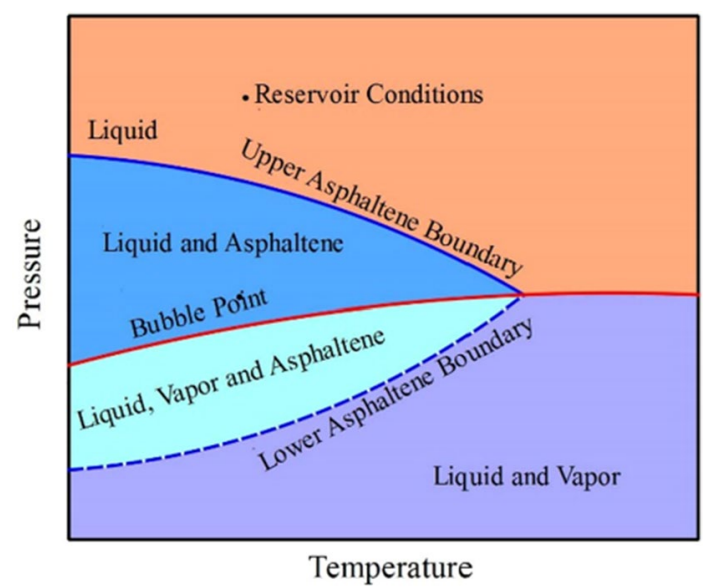

Fig. 13 Asphaltene phase envelope example (Akbarzadeh et al. 2007)

At some point, there will be a solvent-to-bitumen ratio at which asphaltene will begin to precipitate (Czarnecki and Moran 2005). Based on the solvent type, this point will differ significantly (Yeung et al. 1999; Xu et al. 2007). Table 2 shows the point of asphaltene instability using the solvent-to-bitumen ratio for different solvents that are commonly used in the oil industry (Tchoukov et al. 2010). In the table, FL represents the fluid, while RG represents the rigid interface occurring, which signifies the precipitation of asphaltene from solution.

\section{Micro- and nanofluidics}

Micro- and nanofluidics involve the flow in pores or voids that have dimensions less than $100 \mu \mathrm{m}$ for microfluidics and less than $100 \mathrm{~nm}$ for nanofluidics (Mozaffari 2015). These small channels are usually fabricated from low-cost material that is transparent in order to visualize flow in them. The fabrication process includes piranha cleaning and photolithology of the glass followed by micro-/nanochannel etching, and finally glass-bonding to create the channels (Mozaffari et al. 2016). A summary of the previous studies that have utilized micro- and nanofluidics to study the behavior of asphaltene in crude oil is presented in Table 3.

After understanding the asphaltene rheology and flow behavior, it is important to study the mathematical equations and correlations used to model asphaltene flow. Understanding the mathematical models that are used to study asphaltene behavior and predict asphaltene precipitation and deposition is vital in preventing asphaltene problems in the reservoir. The most common mathematical models used to model asphaltene behavior will be mentioned in this research, along with some of their limitations.
Table 2 Solvent-to-bitumen ratio at which asphaltene is instable (Tchoukov et al. 2010)

\begin{tabular}{lcccccccc}
\hline \multicolumn{1}{c}{ S/B } & 1 & 2 & 3 & 4 & 9 & 19 & 32.3 & 99 \\
Bitumen wt.\% & $50 \%$ & $33 \%$ & $25 \%$ & $20 \%$ & $10 \%$ & $5 \%$ & $3 \%$ & $1 \%$ \\
\hline Heptane & FL & RG & RG & & RG & & & \\
Heptol (80:20) & FL & FL & RG & RG & RG & RG & & \\
Heptol (50:50) & FL & & FL & FL & FL & FL & RG & RG \\
Toluene & FL & FL & FL & FL & FL & & FL & \\
\hline
\end{tabular}

Table 3 Summary of micro- and nanofluidic studies involving asphaltene

\begin{tabular}{|c|c|c|}
\hline References & Study & Main observations \\
\hline Mozaffari (2015) & Flow of bitumen in nanofluidic tubes & $\begin{array}{l}\text { Asphaltene aggregates can limit oil flow and create air } \\
\text { pockets }\end{array}$ \\
\hline Mozaffari et al. (2016) & Heavy crude oil rheology and flow & $\begin{array}{l}\text { Solvent-to-bitumen ratio played a strong role in pore } \\
\text { plugging }\end{array}$ \\
\hline Lin et al. (2016) & $\begin{array}{l}\text { Effect of asphaltene solubility on deposition in micro- } \\
\text { channels }\end{array}$ & $\begin{array}{l}\text { The deposition dynamics of asphaltene varied signifi- } \\
\text { cantly with solvent (heptane) concentration }\end{array}$ \\
\hline Keshmiri et al. (2016) & $\begin{array}{l}\text { Analysis of rheology of heavy crude oil using microfluid- } \\
\text { ics }\end{array}$ & $\begin{array}{l}\text { Model developed could not be used to model bitumen } \\
\text { with high accuracy }\end{array}$ \\
\hline Sieben et al. (2016) & $\begin{array}{l}\text { Used a microfluidic approach for measuring the solubil- } \\
\text { ity of asphaltenes in crude oil }\end{array}$ & $\begin{array}{l}\text { The model managed to reduce the required time for } \\
\text { analysis of asphaltene solubility }\end{array}$ \\
\hline Sieben et al. (2017) & $\begin{array}{l}\text { Investigation of asphaltene in crude oil using microfluid- } \\
\text { ics accompanied by a column chromatography }\end{array}$ & $\begin{array}{l}\text { Updated their previous model by including a column } \\
\text { chromatography to fractionate the deasphalted oil }\end{array}$ \\
\hline Afolabi and Yusuf (2019) & Review of using nanotechnology in energy industry & $\begin{array}{l}\text { Review of using nanotechnology for asphaltene flow } \\
\text { inhibition }\end{array}$ \\
\hline Nazemifard (2019) & Asphaltene aggregation kinetics & $\begin{array}{l}\text { Asphaltene played a significant role in the stability of } \\
\text { water-oil emulsions }\end{array}$ \\
\hline
\end{tabular}




\section{Asphaltene mathematical models}

As mentioned previously, asphaltene is extremely complex in structure, and thus, no ubiquitous mathematical equation has been developed to model asphaltene behavior in crude oil. The equations provided in this section were developed based on a specific set of experiments and thus cannot be assuredly applied for all crude oils and all asphaltene structures. Some of these equations attempted to generalize the developed model by using a fitting or scaling parameters, and they are the closest to general model. Two of the most famous equations that have been used as a standard by many researchers over the years include the Hildebrand and the Flory-Huggins models presented in Table 4 (Flory 1941). The Hildebrand model is mostly known for defining the solubility parameter, which works as an indicator of compatibility. If the solubility parameter of a solution is larger than the asphaltene offset pressure, then the asphaltene is generally stable. Once the solubility parameter falls beneath the offset pressure, the asphaltene will begin to precipitate. The Flory-Huggins model is mainly used to obtain the chemical potential. The main drawback of this model is that it lacks an interaction coefficient, and thus, its accuracy is limited to the equation of state used to obtain the solubility parameter. Several other equations developed over the years that tried to evaluate asphaltene are presented in Table 5. The main limitation of these equations is that they were developed for a specific case, and thus, they cannot be generalized to model asphaltene ubiquitously. When applying any of these equations, it is always advised to know the applicability range of the equation and the oil properties used to develop the equation.

\section{Previous asphaltene studies}

In order to better understand asphaltene behavior and problems, previous laboratory and field cases that have both reported asphaltene deposition and have attempted to mitigate asphaltene problems will be presented and explained.

\section{Asphaltene laboratory studies}

Many laboratory studies have been conducted to investigate asphaltene pore plugging in different types of formations. The permeability reduction that occurs due to asphaltene precipitation and deposition during normal production and production during solvent injection was investigated as well. A summary of some of the studies and their reported core properties is shown in Table 6. The sand pack and glass bead experiments used extremely high permeability to investigate asphaltene in unconsolidated formations. The lowest permeability that was experienced was from the shale experiment. The shale experiment utilized gas huff- $n$-puff rather than continuous injection due to the permeability limitation.

Some researchers have mentioned asphaltene pore plugging that was observed in their experimental work as a function of permeability reduction. This is extremely significant, since it shows the extent to which asphaltene can have an impact on oil recovery. A summary of the asphaltene permeability reduction percentage observed in some studies is shown in Table 7 . The permeability reduction is extremely high in some cases, reaching up to $96 \%$. The extent to which asphaltene can reduce permeability is a function of many parameters, however, which is why it is important to investigate the exact value for each case. The factors that may impact asphaltene-induced permeability reduction include core properties, such as porosity, permeability,

Table 4 Hildebrand and Flory-Huggins models

\begin{tabular}{|c|c|c|}
\hline Correlation & Nomenclature & Description \\
\hline$\delta^{\mathrm{L}}=\left(\frac{\Delta H^{\mathrm{L}}-R T}{v^{\mathrm{L}}}\right)^{1 / 2}$ & $\begin{array}{l}\delta^{\mathrm{L}} \text { the solubility parameter of the } \\
\text { asphaltene and oil mixture } \\
v \text { volume }\left(\mathrm{m}^{3} \mathrm{kmol}^{-1}\right) \\
H \text { enthalpy } \\
L \text { liquid } \\
T \text { temperature }(\mathrm{K})\end{array}$ & $\begin{array}{l}\text { The parameters } H^{\mathrm{L}}, v^{\mathrm{L}} \text {, and as a result the solubility parameter } \\
\delta^{\mathrm{L}} \text { are calculated by an equation of state (EOS) }\end{array}$ \\
\hline$\emptyset_{1}^{\mathrm{L}}=\exp \left[\left(\frac{v_{1}^{\mathrm{L}}}{v^{\mathrm{L}}-1}\right)-\left\{\frac{A \delta_{1}^{2}\left(1-\frac{\delta^{\mathrm{L}}}{\delta_{1}}\right)^{2}}{\left(1-f \emptyset_{2}^{\mathrm{L}}\right)}\right\}\right]$ & $\begin{array}{l}\mu \text { chemical potential } \\
T \text { temperature }(\mathrm{K}) \\
\emptyset \text { volume fraction } \\
r \text { molar volume ratio } \\
L \text { liquid, } \delta, f \text { solubility parameters } \\
1 \text { asphaltene } \\
2 \text { oil mixture }\end{array}$ & $\begin{array}{l}\text { Lattice system is required } \\
\text { Assumption: The polymer and solvent molecules arrange } \\
\text { themselves randomly } \\
\text { Flory-Huggins does not account the volume change upon } \\
\text { mixing }\end{array}$ \\
\hline
\end{tabular}


Table 5 Correlations predicting asphaltene properties

\begin{tabular}{|c|c|c|c|}
\hline References & Correlation & Nomenclature & Description \\
\hline $\begin{array}{l}\text { Scott and Magat } \\
\text { (1945) }\end{array}$ & 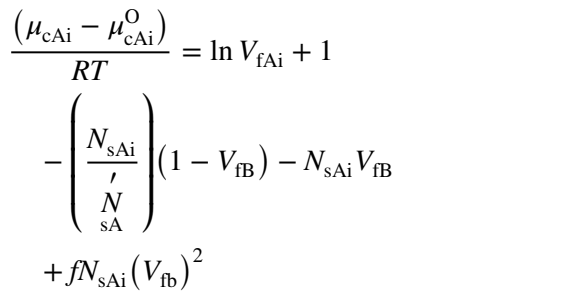 & $\begin{array}{l}A i \text { and } B \text { " } i \text { th" fraction of asphal- } \\
\text { tene and solvent, respectively } \\
V_{\mathrm{f}} \text { volume fraction } \\
f \text { fraction } \\
T \text { temperature, }{ }^{\circ} \mathrm{C} \\
N_{\mathrm{s}} \text { segment number } \\
u \text { chemical potential }\end{array}$ & $\begin{array}{l}\text { Based on Huggins' theory } \\
\text { More general for heterogeneous } \\
\text { polymer/monomer solutions }\end{array}$ \\
\hline $\begin{array}{l}\text { Leontaritis and } \\
\text { Mansoori } \\
\text { (1987) }\end{array}$ & $\ln \emptyset_{\mathrm{r}}=\frac{v_{\mathrm{r}}}{v_{\mathrm{m}}}-\frac{v_{\mathrm{r}}}{R T}\left(\delta_{\mathrm{m}}-\delta_{\mathrm{r}}\right)^{2}-1$ & $\begin{array}{l}\delta_{m} \text { solubility parameter of mixture } \\
\emptyset_{\mathrm{r}} \text { volume fraction of resins in the } \\
\text { mixture } \\
v_{\mathrm{m}} \text { molar volume of mixture, } \mathrm{L}^{3} / \mathrm{n} \\
v_{\mathrm{r}} \text { molar volume of resins, } \mathrm{L}^{3} / \mathrm{n}\end{array}$ & $\begin{array}{l}\text { Asphaltene flocculation prediction } \\
\text { Assumed that asphaltene exists in } \\
\text { the oil as solid particles in colloi- } \\
\text { dal suspension and stabilized by } \\
\text { resins adsorbed on their surface }\end{array}$ \\
\hline $\begin{array}{l}\text { Kawanaka et al. } \\
\text { (1988) }\end{array}$ & $\begin{aligned} V_{\mathrm{fA}}^{\mathrm{L}} & =\int \mathrm{d} V_{\mathrm{fAi}}^{\mathrm{L}} \\
& =\int_{0}^{\infty} \frac{\left(\begin{array}{c}\frac{M_{\mathrm{Ai}}}{\grave{M}} \\
\stackrel{\mathrm{A}}{2}\end{array}\right) V_{\mathrm{A}}^{\mathrm{C}}}{\left(V^{\mathrm{L}}+V^{s} \exp \left(-N_{\mathrm{sAi} \theta}\right)\right.} F\left(M_{\mathrm{Ai}}\right) \mathrm{d} M_{\mathrm{Ai}}\end{aligned}$ & $\begin{array}{l}V_{\mathrm{A}}^{\mathrm{C}} \text { the total volume of asphaltene } \\
\text { in crude oil } \\
V_{\mathrm{f}} \text { volume fraction } \\
M \text { molecular weight } \\
S \text { solid phase } \\
L \text { solvent-rich liquid } \\
N_{\mathrm{s}} \text { segment number } \\
I \text { component identification } \\
F \text { distribution function } \\
f \text { fraction }\end{array}$ & $\begin{array}{l}\text { It can be used to calculate the total } \\
\text { volume fraction of asphaltene in } \\
\text { the liquid phase in equilibrium } \\
\text { with the solid phase }\end{array}$ \\
\hline $\begin{array}{l}\text { de Boer et al. } \\
\text { (1995) }\end{array}$ & $S=\exp \left\{-1+v_{\mathrm{a}}\left[\frac{1}{v_{\mathrm{o}}}-\frac{\left(\delta_{\mathrm{a}}-\delta_{\mathrm{o}}\right)^{2}}{R T}\right]\right\} * C$ & $\begin{array}{l}S \text { asphaltene solubility } \\
C \text { correction term for asphaltene } \\
\text { polymerization and asphaltene- } \\
\text { resin interaction }\end{array}$ & $\begin{array}{l}\text { Based on Hildebrand's asphaltene } \\
\text { solubility parameter of the oil and } \\
\text { asphaltene }\end{array}$ \\
\hline $\begin{array}{l}\text { Rassamdana and } \\
\text { Sahimi (1996) }\end{array}$ & $X=\frac{S}{M^{Z}} Y=\frac{W}{S^{Z^{\prime}}}$ & $\begin{array}{l}S \text { ratio of the volume of injected } \\
\text { solvent to the weight of the crude } \\
\text { oil } \\
M \text { molecular weight solvent } \\
W \text { weight percent } \\
Z, Z^{\prime} \text { constants }\end{array}$ & $\begin{array}{l}\text { Conducted asphaltene precipita- } \\
\text { tion experiments with different } \\
\text { alkanes } \\
\text { Scaling equation on aggregation/ } \\
\text { gelation }\end{array}$ \\
\hline $\begin{array}{l}\text { Ashoori et al. } \\
\text { (2003) }\end{array}$ & $X=\frac{S}{T^{n} M^{Z}} Y=\frac{W}{S^{Z^{\prime}}}$ & $n$ temperature exponent $(0.1-0.25)$ & Introduced the effect of temperature \\
\hline $\begin{array}{l}\text { Mohammadi and } \\
\text { Richon (2007) }\end{array}$ & $x=\frac{v_{\mathrm{m}}\left[\left(\delta_{\mathrm{m}}-\delta_{\mathrm{a}}\right)^{2}\right]+2 l \delta_{\mathrm{m}} \delta_{\mathrm{a}}}{R T}$ & $\begin{array}{l}x \text { maltene solvency power with } \\
\text { respect to the asphaltene } \\
\delta \text { solubility parameter }\end{array}$ & $\begin{array}{l}\text { Does not take into account aggrega- } \\
\text { tion }\end{array}$ \\
\hline $\begin{array}{l}\text { Bagheri et al. } \\
\text { (2009) }\end{array}$ & $X=\frac{S * C_{t} * \mathrm{GOR}}{X_{c 31}+R_{t}} Y=\frac{W * S * R_{t}}{C_{t}}$ & $\begin{array}{r}R_{t} \text { and } C_{t} \text { resin and asphaltene } \\
\text { contents }(\mathrm{wt} \%), \text { respectively }\end{array}$ & - \\
\hline
\end{tabular}

Table 6 Core properties for asphaltene pore plugging experiments

\begin{tabular}{lllllll}
\hline References & Type & Core type & Core length, inch & Core diameter, inch & Porosity, $\%$ & Temperature, ${ }^{\circ} \mathrm{C}$ \\
\hline Martinez et al. (1997) & Thermal crack & Sand pack & 15.75 & 0.5 & - & $425-475$ \\
Ashoori et al. (2006) & Slim tube & Glass beads & 720 & 0.244 & 28 & $30-70$ \\
Fernø et al. (2010) & Core flooding & Chalk & $2.96-3.177$ & $1.99-2.02$ & $45-48$ & 90 \\
Kazempour et al. (2013) & Core flooding & Composite & $10.09-10.42$ & 1.5 & $14.87-17.7$ & 38 and 52 \\
Wang et al. (2016) & Core flooding & Sand pack & 11.81 & 0.984 & $1.49-1.5$ & $28.95-35.19$ \\
Shen and Sheng (2018) & Huff-n-puff & Shale & $1.99-2.0$ & 1.5 & 22 \\
Alrashidi et al. (2018) & Core flooding & Limestone & 6 & & $14.75-16.30$ & 71.11 \\
\hline
\end{tabular}

and mineralogy, and the oil properties, most importantly including the asphaltene concentration and stability in crude oil at different conditions. Another factor that may impact permeability reduction is the oil production rate and the injected solvent type, concentration, phase, and extent to which it interacts with the crude oil. Based on all of this, it 
is important to note that asphaltene permeability reduction is an extremely complex issue that requires extensive study and investigation.

\section{Asphaltene field cases}

Several field studies have reported asphaltene plugging during production, which caused several problems on the rig. Table 8 provides a list of some of these cases and their reported thermodynamic conditions. None of the field cases involve unconventional reservoirs due to lack of investigation of asphaltene in unconventional reservoirs, especially for field cases. Most of the reservoirs are at high temperatures and moderately high pressures, which are two parameters that greatly impact asphaltene stability.

As reported in the laboratory studies, asphaltene pore plugging has also been reported to cause severe permeability reduction and oil recovery reduction in many field studies worldwide. A summary of some of these case studies is presented in Table 9. Based on the permeability reduction for these fields, it is clear that asphaltene pore plugging is an extremely severe matter, and understanding how to prevent asphaltene plugging and how to mitigate asphaltene problems is important in saving both additional costs and time and also to reduce safety concerns.

Asphaltene mitigation is extremely complex since many of the chemicals used to remedy asphaltene problems have several severe drawbacks, such as being incompatible with

Table 7 Asphaltene permeability reduction values for different studies

\begin{tabular}{lllllcc}
\hline References & Type & Core type & Core length (in) & Core diameter (in) & $\begin{array}{c}\text { Permeability (mD) } \\
\text { Permeability } \\
\text { reduction (\%) }\end{array}$ \\
\hline Lichaa and Herrera (1975) & Core flooding & Sand pack & 12.2 & 2.87 & - & $33-96$ \\
Shedid and Zekri (2006) & Core flooding & Carbonate & $2.3-2.6$ & $1.5-1.7$ & $4.97-20.03$ & $4.29-53.52$ \\
Cruz et al. (2009) & Core flooding & Limestone & 2 & 1.5 & $20.9-22.6$ & $24-48$ \\
Behbahani et al. (2012) & Core flooding & Sandstone & 11.81 & 1.575 & 1.4 & $9.25-12.8$ \\
Kord et al. (2012) & Core flooding & Carbonate & $3.374-3.516$ & $1.45-1.5$ & 50 \\
Soroush et al. (2014) & Core flooding & Sand pack & 15.748 & 1.5 & $850-1520$ & $8.2-80$ \\
\hline
\end{tabular}

Table 8 Thermodynamic conditions for some field cases reporting asphaltene problems

\begin{tabular}{lllllll}
\hline References & Field name & Field location & Formation type & Depth (ft) & Temperature $\left({ }^{\circ} \mathrm{C}\right)$ & Pressure (psi) \\
\hline Thawer et al. (1990) & Ula & Norway & Sandstone & $10,974.4$ & 143 & 7114.68 \\
Thomas et al. (1995) & - & Mexico & Sandstone & 19,600 & 200 & - \\
Jamaluddin et al. 2000 & Sahil & United Arab Emirates & - & 8860 & 123.89 & 4425 \\
Kalantari-Dahagi et al. (2006) & Kupal & Iran & Carbonate & - & 71.11 & 6000 \\
Yonebayashi et al. (2011) & Arabian Gulf & United Arab Emirates & Carbonate & - & 104.44 & - \\
\hline
\end{tabular}

Table 9 Summary of some field cases involving asphaltene

\begin{tabular}{|c|c|c|c|c|c|c|}
\hline References & Field name & Field location & Formation type & $\begin{array}{l}\text { Perme- } \\
\text { ability } \\
\text { (md) }\end{array}$ & $\begin{array}{l}\text { Permeability } \\
\text { reduction }(\%)\end{array}$ & Outcome \\
\hline Thomas et al. (1995) & - & Mexico & Sandstone & - & - & $\begin{array}{l}\text { Production decreased from } 4700 \text { to } 436 \\
\text { BPD }\end{array}$ \\
\hline Thomas et al. (1995) & - & Louisiana & - & - & - & $\begin{array}{l}\text { Production decreased from } 406 \text { to } 53 \\
\text { BPD }\end{array}$ \\
\hline Thomas et al. (1995) & - & Mexico & - & - & - & Plugged completely \\
\hline Kalantari-Dahagi et al. (2006) & Kupal & Iran & Carbonate & - & $45-90$ & - \\
\hline Al-Ghazi and Lawson (2007) & Ghawar & Saudi Arabia & Limestone & 617 & - & $\begin{array}{l}\text { Complete flow restriction due to asphal- } \\
\text { tene precipitation }\end{array}$ \\
\hline Uetani (2014) & - & Japan & - & - & - & $\begin{array}{l}\text { Wettability alteration by asphaltene } \\
\text { deposition }\end{array}$ \\
\hline
\end{tabular}


Table 10 Asphaltene treatment methods and their outcomes

\begin{tabular}{|c|c|c|c|c|}
\hline References & Field location & Treatment type & Treatment method & Outcome \\
\hline Schantz and Stephenson (1991) & North Dakota & Chemical & Xylene & $\begin{array}{l}\text { Production increased from } 42 \text { to } 60 \\
\text { BPD after dispersant A }\end{array}$ \\
\hline Schantz and Stephenson (1991) & Wyoming & Chemical & $\begin{array}{l}\text { Using dispersant A and a solids/ } \\
\text { paraffin dispersant to help suspend } \\
\text { entrapped solids }\end{array}$ & Oil recovery increased by $33 \%$ \\
\hline Thomas et al. (1995) & Mexico & Chemical & $\begin{array}{l}\text { Xylene and several additives } \\
\text { For tubing: mixture of xylene (90\%) } \\
\text { and product } 1(10 \%) \\
\text { For formation: a mutual solvent } \\
\text { followed by a mixture of product } 3 \\
\text { and } 10 \% \text { of xylene }\end{array}$ & $\begin{array}{l}\text { Production increased from } 436 \text { to } 4800 \\
\text { BPD }\end{array}$ \\
\hline Thomas et al. (1995) & Louisiana & Chemical & $\begin{array}{l}\text { Xylene } \\
\text { Product } 2 \text { with mutual solvent } \\
\text { preflush }\end{array}$ & $\begin{array}{l}\text { Xylene increased production from } 53 \\
\text { to } 101 \mathrm{BPD} \text { and then it decreased to } \\
66 \mathrm{BPD} \\
\text { Second treatment, production increased } \\
\text { to } 152 \text { and then stabilized at } 91 \mathrm{BPD}\end{array}$ \\
\hline Yen et al. (2001) & West Texas & Chemical & - & $\begin{array}{l}\text { Production increased from } 40 \text { BPD to } \\
\text { slightly more than } 100 \mathrm{BPD}\end{array}$ \\
\hline Al-Ghazi and Lawson (2007) & Saudi Arabia & & $\begin{array}{l}\text { Displace the asphaltene from the tub- } \\
\text { ing by bull heading water } \\
\text { Xylene bullhead was attempted (but } \\
\text { the rate of penetration was insuf- } \\
\text { ficient to break through asphaltene) } \\
\text { Workover was considered the next } \\
\text { best option }\end{array}$ & First method was unsuccessful \\
\hline Uetani (2014) & Japan & Chemical & Xylene & $\begin{array}{c}\text { Productivity recovered and water cut } \\
\text { decreased from } 10-15 \% \text { to } 2-3 \%\end{array}$ \\
\hline
\end{tabular}

the reservoir fluids, high in cost, environmentally unfriendly, or unstable at reservoir conditions. Several researchers have therefore developed different formulations that were deemed more stable than the pure chemicals. The main drawback is that the exact formulation for these chemicals is usually not reported, and thus, they will be given code names in the table based on how the original researchers referred to them. Table 10 presents the field mitigation methods after asphaltene problems arose and the outcomes obtained from each method, including the oil recovery increase and the overall success of the mitigation process. Many of the studies have utilized xylene, either in its pure form or as a component of a formulation. This indicates that xylene has a strong ability to reduce asphaltene problems by dissolving the asphaltene deposits.

\section{Conclusion}

This research presents a review of asphaltene in crude oil and the factors that have the strongest impact on asphaltene stability in crude oil. The different models attempting to describe the asphaltene structure were explained, and the most recent and widely accepted model, Yen-Mullins, was described. Asphaltene phases in the crude oil were also mentioned and explained in detail, including asphaltene precipitation, flocculation, dissociation, and deposition. The main factors impacting asphaltene instability were mentioned as well, including operational and reservoir factors. Also, the main chemical methods used to analyze asphaltene structure and composition were mentioned, along with the different experiments conducted to investigate asphaltene permeability reduction and pore plugging. Finally, several field studies that encountered asphaltene problems were mentioned, and the methods by which they attempted to mitigate the asphaltene problem were mentioned, along with the outcome of each method.

Acknowledgements The author wishes to thank Missouri University of Science and Technology for its support through the Chancellors Distinguished Fellowship.

Open Access This article is licensed under a Creative Commons Attribution 4.0 International License, which permits use, sharing, adaptation, distribution and reproduction in any medium or format, as long as you give appropriate credit to the original author(s) and the source, provide a link to the Creative Commons licence, and indicate if changes were made.The images or other third party material in this article are included in the article's Creative Commons licence, unless indicated otherwise in a credit line to the material. If material is not included in the article's Creative Commons licence and your intended use is not permitted by statutory regulation or exceeds the permitted use, you will 
need to obtain permission directly from the copyright holder.To view a copy of this licence, visit http://creativecommons.org/licenses/by/4.0/.

\section{References}

Abdel-Raouf M (2012) Factors affecting the stability of crude oil emulsions. In: Crude oil emulsions - composition stability and characterization. Manar El-Sayed Abdel-Raouf, IntechOpen. https:// doi.org/10.5772/35018. Available from: https://www.intechopen .com/books/crude-oil-emulsions-composition-stability-and-chara cterization/factors-affecting-the-stability-of-crude-oil-emulsions

Afolabi R, Yusuf E (2019) Nanotechnology and global energy demand: challenges and prospects for a paradigm shift in the oil and gas industry. J Pet Explor Prod Technol 2019(9):1423-1441. https:// doi.org/10.1007/s13202-018-0538-0

Ahmadi MA (2011) Prediction of asphaltene precipitation using artificial neural network optimized by imperialist competitive algorithm. J Pet Explor Prod Technol 1:99. https://doi.org/10.1007/ s13202-011-0013-7

Akbarzadeh $\mathrm{K}$ et al (2007) Asphaltenes-problematic but rich in potential. Oilfield Rev 19(2):22-43

Al-Ghazi S, Lawson J (2007) Asphaltene cleanout using vibrablaster tool. Soc Pet Eng. https://doi.org/10.2118/110972-MS

Alrashidi H, Farid Ibrahim A, Nasr-El-Din H (2018, June 22) Bio-oil dispersants effectiveness on asphaltene sludge during carbonate acidizing treatment. Soc Pet Eng. https://doi.org/10.2118/19116 5-ms

Alshaikh M et al (2018) An innovative dielectric constant measurement method to determine the ideal surfactant candidate to enhance heavy oil recovery. Soc Pet Eng. https://doi.org/10.2118/18975 2-MS

Alshaikh M et al (2019) Anionic surfactant and heavy oil interaction during surfactant-steam process. Soc Pet Eng. https://doi. org/10.2118/195254-MS

Alvarez-Ramirez F, Ruiz-Morales Y (2003) Island versus archipelago architecture for asphaltenes: polycyclic aromatic hydrocarbon dimer theoretical studies. Energy Fuels 27(4):1791-1808. https ://doi.org/10.1021/ef301522m

Angle CW, Hua Y (2012) Dilational interfacial rheology for increasingly deasphalted bitumens and $n$-C5 asphaltenes in toluene/ $\mathrm{NaHCO}_{3}$ solution. Energy Fuels 26(10):6228-6239. https://doi. org/10.1021/ef300846z

Ashoori S, Jamialahmadi M, Müller Steinhagen H, Ahmadi K (2006) Investigation of reversibility of asphaltene precipitation and deposition for an Iranian crude oil. Iran J Chem Chem Eng (IJCCE) 25(3):41-47

Ashoori J, Muller S, Ahmadi K (2003) A New Scaling Equation for Modeling of Asphaltene Precipitation. Soc Pet Eng. https://doi. org/10.2118/85673-MS

Bagheri MB, Mirzabozorg A, Kharrat R, Dastkhan Z, Ghotbi C (2009) Developing a new scaling equation for modelling of asphaltene precipitation. In: Canadian international petroleum conference (CIPC), Calgary, 16-18 June 2009

Bahzad D, Al-Fadhli J, Al-Dhafeeri A, Abdal A (2010) Assessment of selected apparent kinetic parameters of the HDM and HDS reactions of two Kuwaiti RESIDUAL oils, using two types of commercial ARDS catalysts. Energy Fuels 24:1495-1501

Behbahani TJ, Ghotbi C, Taghikhani V, Shahrabadi A (2012) Investigation on asphaltene deposition mechanisms during $\mathrm{CO}_{2}$ flooding processes in porous media: a novel experimental study and a modified model based on multilayer theory for asphaltene adsorption. Energy Fuels 26(8):5080-5091. https://doi. org/10.1021/ef300647f
Bissada KA et al (2016) Group-type characterization of crude oil and bitumen. Part II: efficient separation and quantification of normal-paraffins iso-paraffins and naphthenes (PIN). Fuel 173:217-221

Boussingault JB (1837) Mémoire sur la composition des bitumes. Ann Chim Phys 64:141-151

Burke $\mathrm{N}$ et al (1990) Measurement and modeling of asphaltene precipitation (includes associated paper 23831). J Pet Technol 42(11):1440-1446

Castillo J et al (2009) Measurement of the refractive index of crude oil and asphaltene solutions: onset flocculation determination. Energy Fuels 24(1):492-495

Cendejasa G, Arreguina A, Laura Castroa V, Floresa Eugenio A, Vazqueza F (2013) Demulsifying super-heavy crude oil with bifunctionalized block copolymers. Fuel 03:356-363

Cho Y, Na J-G, Nho n-S, Kim S, Kim S (2012) Application of saturates, aromatics, resins, and asphaltenes crude oil fractionation for detailed chemical characterization of heavy crude oils by Fourier transform ion cyclotron resonance mass spectrometry equipped with atmospheric pressure photoionization. Energy Fuels 26:2558-2565

Cruz JL, Argüelles-Vivas FJ, Matías-Pérez V, Durán-Valencia CD, López-Ramírez S (2009) Asphaltene-induced precipitation and deposition during pressure depletion on a porous medium: an experimental investigation and modeling approach. Energy Fuels 23(11):5611-5625. https://doi.org/10.1021/ef9006142

Czarnecki J, Moran K (2005) On the stabilization mechanism of water-in-oil emulsions in petroleum systems. Energy Fuels 19(5):2074-2079. https://doi.org/10.1021/ef0501400

D-4124-97, ASTM. Standard Test Methods for Separation of Asphalt into Four Fractions. Updated 2019

De Boer RB et al (1995) Screening of crude oils for asphalt precipitation: theory, practice, and the selection of inhibitors. SPE Prod Facil 10(1):55-61

Ekulu G et al (2004) Scanning aggregation phenomena in crude oils with density measurements. J Dispers Sci Technol 25(3):321-331

Elkahky S et al (2019) A comparative study of density estimation of asphaltene structures using group contribution methods and molecular dynamic simulations for an Australian oil field. J Petrol Explor Prod Technol 9:2699. https://doi.org/10.1007/s1320 2-019-0641-x

Fakher S, Imqam A (2018a, October 29). Investigating and mitigating asphaltene precipitation and deposition in low permeability oil reservoirs during carbon dioxide flooding to increase oil recovery. Soc Pet Eng. https://doi.org/10.2118/192558-ms

Fakher S, Imqam A (2018b) Asphaltene precipitation and deposition during $\mathrm{CO}_{2}$ injection in nano shale pore structure and its impact on oil recovery. Fuel 237:1029-1039. https://doi.org/10.1016/j. fuel.2018.10.039

Fakher S, Imqam A, Wanas E (2018, December 10). Investigating the viscosity reduction of ultra-heavy crude oil using hydrocarbon soluble low molecular weight compounds to improve oil production and transportation. Soc Pet Eng. https://doi. org/10.2118/193677-ms

Fakher S et al (2019) An experimental investigation of asphaltene stability in heavy crude oil during carbon dioxide injection. J Petrol Explor Prod Technol. https://doi.org/10.1007/s13202-019-00782 $-7$

Fan T et al (2002) Evaluating crude oils by SARA analysis. Presented at the SPE/DOE improved oil recovery symposium, Tulsa, Oklahoma, 13-17 April. SPE-75228-MS

Fan H (2003) The effects of reservoir minerals on the composition changes of heavy oil during steam stimulation. J Can Pet Technol 42(3):11-14 
Fernø MA, Torsvik M, Haugland S, Graue A (2010) Dynamic laboratory wettability alteration. Energy Fuels 24(7):3950-3958. https ://doi.org/10.1021/ef1001716

Flory (1941) Thermodynamics of high polymer solutions. J Chem Phys 9:660. https://doi.org/10.1063/1.1750971

Forte E, Taylor SE (2014) Thermodynamic modelling of asphaltene precipitation and related phenomena. Adv Coll Interface Sci 217:1-12

Garner W, Ham J (1939) The combustion of methane. R Soc A. https ://doi.org/10.1098/rspa.1939.0019

Gholami A et al (2016) Improving the estimation accuracy of titrationbased asphaltene precipitation through power-law committee machine (PLCM) model with alternating conditional expectation (ACE) and support vector regression (SVR) elements. J Pet Explor Prod Technol 6:265. https://doi.org/10.1007/s1320 2-015-0189-3

Goel P et al (2017) Prediction of API values of crude oils by use of saturates/aromatics/resins/asphaltenes analysis: computational-intelligence-based models. Soc Pet Eng J. https://doi. org/10.2118/184391-PA

Golkari A, Riazi M (2017) Experimental investigation of miscibility conditions of dead and live asphaltenic crude oil- $\mathrm{CO}_{2}$ systems. J Pet Explor Prod Technol 7:597. https://doi.org/10.1007/s1320 2-016-0280-4

Goual L (2012) Petroleum asphaltenes, crude oil emulsions-composition stability and characterization. ISBN: 978-953-51-0220-5

Goual L, Abudu A (2009) Predicting the adsorption of asphaltenes from their electrical conductivity. Energy Fuel 24:469-474

Groenzin H, Mullins OC (2000) Molecular size and structure of asphaltenes from various sources. Energy Fuels 14(3):677-684

Hammami A et al (2000) Asphaltene precipitation from live oils: an experimental investigation of onset conditions and reversibility. Energy Fuels 14(1):14-18

Hannisdal A, Ese MH, Hemmingsen PV, Sjoblom J (2006) Particlestabilized emulsions: effect of heavy crude oil components preadsorbed onto stabilizing solids. Colloids Surf A Physicochem Eng. Aspects 276:45-58

Hernandez ME, Vives MT, Pasquali J (1983) Relationships among viscosity, composition, and temperature for two groups of heavy crudes from the eastern Venezuelan basin. Org Geochem 4:173-178

Ihtsham M, Ghosh B (2015) Dynamic asphaltene deposition control in pipe flow through the application of DC potential. J. Pet Explor Prod Technol 5:99. https://doi.org/10.1007/s13202-014-0113-2

Iraji S, Ayatollahi S (2019) Experimental investigation on asphaltene biodegradability using microorganism: cell surface properties' approach. J Pet Explor Prod Technol 9:1413. https://doi. org/10.1007/s13202-018-0537-1

Islas-Flores CA, Buenrostro-Gonzalez E et al (2005) Comparisons between open column chromatography and HPLC SARA fractionations in petroleum. Energy Fuels 19(5):2080-2088

Jamaluddin AKM et al (2000) Experimental and theoretical assessment of the asphaltene precipitation characteristics of the Sahil field under a proposed gas injection scheme. In: Paper SPE \# 87292 presented at the SPE Conf. and Exh., 15-18 October 2000, Abu Dhabi, UAE

Jewell D et al (1972) Ion-exchange, coordination, and adsorption chromatographic separation of heavy-end petroleum distillates. Anal Chem 44(8):1391-1395

Jha NK et al (2014) Characterization of crude oil of upper Assam field for flow assurance. Presented at the SPE Saudi Arabia Section Annual Technical Symposium and Exhibition, Al-Khobar, Saudi Arabia, 21-24 April. SPE-172226-MS

Kalantari-Dahagi A et al (2006) Formation damage due to asphaltene precipitation resulting from $\mathrm{CO}_{2}$ gas injection in Iranian carbonate reservoirs. Soc Pet Eng. https://doi.org/10.2118/99631-MS
Kargarpour MA, Dandekar A (2016) Analysis of asphaltene deposition in Marrat oil well string: a new approach. J Petrol Explor Prod Technol 6:845. https://doi.org/10.1007/s13202-015-0221-7

Karlsen DA, Larter SR (1991) Analysis of petroleum fractions by TLC-FID: applications to petroleum reservoir description. Org Geochem 17(5):603-617

Kawanaka S, Park SJ, Mansooori GA (1988) The role of asphaltene deposition in EOR gas flooding: a predictive technique. Soc Pet Eng DOE SPE 17376:617-627

Kazempour M, Manrique EJ, Alvarado V, Zhang J, Lantz M (2013) Role of active clays on alkaline-surfactant-polymer formulation performance in sandstone formations. Fuel 104:593-606. https ://doi.org/10.1016/j.fuel.2012.04.034

Keshmiri K et al (2016) Using microfluidic device to study rheological properties of heavy oil. In: 16th AIChE annual meeting, San Francisco, CA, USA

Keshmirizadeh E, Shobeirian S, Memariani M (2013) Determination of saturates, aromatics, resins and asphaltenes (SARA) fractions in Iran crude oil sample with chromatography methods: study of the geochemical parameters. J Appl Chem Res 7(4):15-24

Khamehchi E, Shakiba M, Ardakani MS (2018) A novel approach to oil production optimization considering asphaltene precipitation: a case study on one of the Iranian south oil wells. J Pet Explor Prod Technol 8:1303. https://doi.org/10.1007/s13202-017-0409-0

Kharrat A et al (2013) Asphaltene content measurement using an optical spectroscopy technique. Energy Fuels 27(5):2452-2457. https ://doi.org/10.1021/ef400050y

Kim ST et al (1990) The role of asphaltene in wettability reversal. In: SPE Paper presented at the SPE Annual Technical Conference and Exhibition, 1990, New Orleans, Louisiana

Kok MV, Karacan O, Pamir R (1998) Kinetic analysis of oxidation behaviour of crude oil SARA constituents. Energy Fuels 12-3:580-588

Kor P et al (2017) Comparison and evaluation of several models in prediction of asphaltene deposition profile along an oil well: a case study. J Pet Explor Prod Technol 7:497. https://doi.org/10.1007/ s13202-016-0269-Z

Kord S, Miri R, Ayatollahi S, Escrochi M (2012) Asphaltene deposition in carbonate rocks: experimental investigation and numerical simulation. Energy Fuels 26(10):6186-6199. https://doi. org/10.1021/ef300692e

Kuznicki T et al (2008) Molecular dynamics study of model molecules resembling asphaltene-like structures in aqueous organic solvent systems. Energy Fuels 22(4):2379-2389. https://doi.org/10.1021/ ef800057n

Lammoglia T, Filho CRdS (2011) Spectroscopic characterization of oils yielded from Brazilian offshore basins: potential applications of remote sensing. Remote Sens Env 115:2525-2535

Leandra $S$ et al (2018) Stress relaxation in quasi-two-dimensional selfassembled nanoparticle monolayers. Phys Rev E 96(5):052803. https://doi.org/10.1103/PhysRevE.97.052803

Leon O, Contreras E, Rogel E, Dambakli G, Acevedo S, Carbognani L, Espidel J (2002) Adsorption of native resins on asphaltene particles: a correlation between adsorption and activity. Langmuir 18:5106-5112

Leontaritis K, Mansoori GA (1987) Asphaltene flocculation during oil production and processing: a thermodynamic collodial model. In: SPE international symposium on oilfield chemistry. Society of Petroleum Engineers

Liao $\mathrm{H}$ et al (2019) Effect of crude oil composition on microwave absorption of heavy Oils. Soc Pet Eng. https://doi. org/10.2118/195263-MS

Lichaa PM, Herrera L (1975) Electrical and other effects related to the formation and prevention of asphaltene deposition problem in Venezuelan crudes. In: SPE oilfield chemistry symposium. Society of Petroleum Engineers 
Lin Y et al (2016) Examining asphaltene solubility on deposition in model porous media. Langmuir 32(34):8729-8734. https://doi. org/10.1021/acs.langmuir.6b02376

Liu F et al (2017) Mixture effect on the dilatation rheology of asphaltenes-laden interfaces. Langmuir 33:8. https://doi. org/10.1021/acs.langmuir.6b03958

Martinez MT, Benito AM, Callejas MA (1997) Thermal cracking of coal residues: kinetics of asphaltene decomposition. Fuel 76(9):871-877

Miadonye A, Evans L (2010) The solubility of asphaltenes in different hydrocarbon liquids. Pet Sci Technol J. https://doi. org/10.1080/10916460902936960

Mishra VK et al (2012) Downhole fluid analysis and asphaltene nanoscience coupled with VIT for risk reduction in black oil production. Presented at the SPE annual technical conference and exhibition, San Antonio, USA, 8-10

Mohammadi AH, Richon D (2007) A monodisperse thermodynamic model for estimating asphaltene precipitation. AIChE J 53(11):2940-2947

Monger TG, Fu JC (1987) The nature of $\mathrm{CO}_{2}$-induced organic deposition. In: SPE paper \# 16713 presented at the SPE Annual Technical Conference and Exhibition, Houston, TX

Mozaffari S (2015) Rheology of Bitumen at the onset of asphaltene aggregation and its effects on the stability of water-in-oil emulsion. Masters Thesis, University of Alberta, Canada

Mozaffari S et al (2015) Effect of asphaltene aggregation on rheological properties of diluted athabasca bitumen. Energy Fuels 29(9):5595-5599. https://doi.org/10.1021/acs.energyfuel s.5b00918

Mozaffari S et al (2016) Capillary driven flow in nanochannels-application to heavy oil rheology studies. Colloids Surf A 513(5):178187. https://doi.org/10.1016/j.colsurfa.2016.10.038

Mozaffari S et al (2017a) Capillary driven flow in nanochannelsapplication to heavy oil rheology studies. Colloids Surf A 513:178-187. https://doi.org/10.1016/j.colsurfa.2016.10.038

Mozaffari S et al (2017b) Colloidal nanoparticle size control: experimental and kinetic modeling investigation of the ligand-metal binding role in controlling the nucleation and growth kinetics. Nanoscale 9(36):13772-13785. https://doi.org/10.1039/C7NR0 4101B

Mozaffari S et al (2018) Ligand-mediated nucleation and growth of palladium metal nanoparticles. J Vis Exp 136:e57667. https:// doi.org/10.3791/57667

Mullins OC (2010) The modified yen model. Energy Fuels 24(4):2179-2207

Mullins OC (2011) The asphaltenes. Ann Rev. Anal Chem 4:393-418

Mullins OC et al (2013) Asphaltene nanoscience and reservoir fluid gradients, tar mat formation, and the oil-water interface. Presented at the SPE annual technical conference and exhibition, Louisiana, USA, 30 Sept 2 Oct

Nazemifard N (2019) Application of micro/nanofluidics in energy. Fluids at Brown, Division of Applied Mathematics, Fluids and Thermal Sciences, School of Engineering, Joint Seminar Series

Nghiem LX, Coombe DA (1997) Modelling asphaltene precipitation during primary depletion. SPE J 2(02):170-176

Nwadinigwe $C$ et al (2015) Studies on precipitation performance of $n$-heptane and $n$-pentane/ $n$-heptane on $\mathrm{C} 7$ and $\mathrm{C} 5 / \mathrm{C} 7$ asphaltenes and maltenes from $350 \mathrm{C}$ atmospheric residuum of three Nigerian light crudes. J Pet Explor Prod Technol 5:403. https://doi. org/10.1007/s13202-014-0150-x

Pazuki GR (2007) Application of a new cubic equation of state to computation of phase behavior of fluids and asphaltene precipitation in crude oil. Fluid Phase Equilib 254(1):42-48

Pearson CD, Gharfeh SG (1986) Automated high-performance liquid chromatography determination of hydrocarbon types in crude oil residues using a flame ionization detector. Anal Chem 58(2):307-311

Prakoso AA et al (2017) A mechanistic understanding of asphaltenes precipitation from varying-saturate-concentration perspectives. Soc Pet Eng. https://doi.org/10.2118/177280-PA

Punase A et al (2016) The polarity of crude oil fractions affects the asphaltenes stability. Soc Pet Eng. https://doi.org/10.2118/18042 3-MS

Rassamdana H, Sahimi M (1996) Asphalt flocculation and deposition: II. Formation and growth of fractal aggregates. AIChE J 42(12):3318-3332

Rassamdana HB et al (1996) Asphaltene flocculation and deposition: I. The onset of precipitation. AIChE J 42(1):10-22

Rogel E et al (1999) Asphaltene stability in crude oils. Soc Pet Eng. https://doi.org/10.2118/53998-MS

Salleh IK et al (2019) Micro-emulsion-based dissolver for removal of mixed scale deposition. J Pet Explor Prod Technol 9:2635. https ://doi.org/10.1007/s 13202-019-0643-8

Schantz S, Stephenson W (1991) Asphaltene deposition: development and application of polymeric asphaltene dispersants. Soc Pet Eng. https://doi.org/10.2118/22783-MS

Scott RL, Magat M (1945) The thermodynamics of high-polymer solutions: the free energy of mixing of solvents and polymers of heterogeneous distribution. J Chem Phys. 13(5):172-177

Seifert DJ et al (2012) Black oil, heavy oil, and tar in one oil column understood by simple asphaltene nanoscience. Presented at the Abu Dhabi international petroleum exhibition \& conference, UAE, 11-14 November

Seifried C et al (2013) Kinetics of asphaltene aggregation in crude oil studied by confocal laser-scanning microscopy. Energy Fuels 27:1865-1872

Shedid and Zekri (2006) Formation damage caused by simultaneous sulfur and asphaltene deposition. Soc Pet Eng. https://doi. org/10.2118/86553-PA

Shen and Sheng (2018) Experimental and numerical study of permeability reduction caused by asphaltene precipitation and deposition during $\mathrm{CO}_{2}$ huff and puff injection in Eagle Ford shale. Fuel 211:432-445. https://doi.org/10.1016/j.fuel.2017.09.047

Sieben V et al (2016) Microfluidic approach for evaluating the solubility of crude oil asphaltenes. Energy Fuels 30(3):1933-1946. https ://doi.org/10.1021/acs.energyfuels.5b02216

Sieben V et al (2017) Optical measurement of saturates, aromatics, resins, and asphaltenes in crude oil. Energy Fuels 31(4):3684-3697. https://doi.org/10.1021/acs.energyfuels.6b03274

Soleymanzadeh A et al (2018) A review on methods of determining onset of asphaltene precipitation. J Pet Explor Prod Technol 2019(9):1375-1396. https://doi.org/10.1007/s13202-018-0533-5

Soroush $\mathrm{S}$ et al (2014) A comparison of asphaltene deposition in miscible and immiscible carbon dioxide flooding in porous media. Soc Pet Eng. https://doi.org/10.2118/169657-MS

Speight JG (1999) The chemical and physical structure of petroleum: effect on recovery operations. J Pet Sci Eng 22:3-15

Speight JG et al (1985) Molecular weight and association of asphaltenes: a critical review. Revue De L'Institut FrancaisDu Petrole 40(1):51-61

Struchkov IA et al (2019) Laboratory investigation of asphalteneinduced formation damage. J Pet Explor Prod Technol 9:1443. https://doi.org/10.1007/s13202-018-0539-z

Tchoukov P et al (2010) Study of water-in-oil thin liquid films: implications for the stability of petroleum emulsions. Colloids Surf A Physicochem Eng Aspects 372(1-3):15-21. https://doi. org/10.1016/j.colsurfa.2010.09.007

Thawer R et al (1990) Asphaltene deposition in production facilities. Soc Pet Eng. https://doi.org/10.2118/18473-PA 
Theyab MA et al (2017) Study of fluid flow assurance in hydrocarbon production-investigation wax mechanisms. PhD Thesis, London South Bank University

Thomas D et al (1995) Controlling asphaltene deposition in oil wells. Soc Pet Eng. https://doi.org/10.2118/25483-PA

Uetani T (2014, November 10) Wettability alteration by asphaltene deposition: a field example. Soc Pet Eng. https://doi. org/10.2118/171788-ms

Wang J, Buckley J (2001) A two-component solubility model of the onset of asphaltene flocculation in crude oils. Energy Fuels 15(5):1004-1012

Wang $\mathrm{S}$ et al (2016) Characterization of produced and residual oils in the $\mathrm{CO}_{2}$ flooding process. Energy Fuels 30(1):54-62. https://doi. org/10.1021/acs.energyfuels.5b01828

$\mathrm{Xu} \mathrm{Y}$ et al (2007) Destabilization of water in bitumen emulsion by washing with water. J Pet Sci Technol 17(9):1051-1070. https:// doi.org/10.1080/10916469908949765

Yarranton HW, Alboudwarej H, Jakher R (2000) Investigation of asphaltene association with vapor pressure osmometry and interfacial tension measurements. Ind Eng Chem Res 39(8):2916-2924

Yen A et al (2001) Evaluating asphaltene inhibitors: laboratory tests and field studies. In: Paper SPE -65376-MS presented at the SPE international symposium on oilfield chemistry 2001, Houston, Texas

Yeung A et al (1999) On the interfacial properties of micrometre-sized water droplets in crude oil. R Society A. https://doi.org/10.1098/ rspa.1999.0473

Yonebayashi H et al (2011) Dynamic asphaltene behavior for gasinjection risk analysis. Soc Pet Eng Reserv Eval Eng J. https:// doi.org/10.2118/146102-PA

Zendehboudi $S$ et al (2013) Thermodynamic investigation of asphaltene precipitation during primary oil production: laboratory and smart technique. Ind Eng Chem Res 52(17):6009-6031

Zendehboudi S et al (2014) Asphaltene precipitation and deposition in oil reservoirs-technical aspects, experimental and hybrid neural network predictive tools. Chem Eng Res Des 92(5):857-875

Publisher's Note Springer Nature remains neutral with regard to jurisdictional claims in published maps and institutional affiliations. 